\title{
Indian Students at a Russian Regional University: Socio-economic Impact of Short-term Educational Programmes ${ }^{1}$
}

Universities are increasingly seen as drivers of regional economic development. In this research, we undertook an analysis of the short-term academic mobility of university students as a factor in the internationalisation of higher education. The number of foreign students (International Student Ratio) attracted from across the world is an important metric in all global university rankings. As a result, universities aiming to improve their positions in the global educational market are actively implementing programmes to attract foreign students. Short-term educational programmes of academic mobility are characterised by a high level of flexibility in terms of management, thus being capable of meeting a wide range of needs and interests of potential students. In July 2019, we conducted a survey among Indian students $(n=65)$ participating in short-term international academic mobility programmes at the Ural Federal University (Ekaterinburg, Russia). The main goal of the empirical research was to investigate students' motivational structure of participation in academic mobility and the role of such programmes in the implementation of students' life plans. In addition, barriers to the effective implementation of short-term educational programmes at universities were revealed. According to the research results, Russian education is a status characteristic for Indian students, which allows them to gain important socio-cultural and communicative competencies, as well as to build professional trajectories in a foreign country. The respondents expressed willingness to continue their education in Russia as part of Master's degree educational programmes. Among the main barriers and challenges, the respondents mentioned poor knowledge of the Russian language and financial difficulties.

Keywords: internationalisation, university, academic mobility, short-term programs, Indian students

\section{Acknowledgements}

The article has been prepared with the support of the grant No. 18-18-00236 of the Russian Science Foundation awarded to the Ural Federal University.

For citation: Antonova, N. L., Kumar, D. A., Popova, G. I. \& Vysotskaya, Ya. S. (2021). Indian Students at a Russian Regional University: Socio-economic Impact of Short-term Educational Programmes. Ekonomika regiona [Economy of region], 17(2), 460-472, https://doi.org/10.17059/ekon.reg.2021-2-8

\footnotetext{
1 ( ) Antonova, N. L., Kumar, D. A., Popova, G. I. \& Vysotskaya, Ya. S. Text. 2021.
} 


\author{
Н. Л. Антонова ${ }^{\text {a) }}$, Д. А. Кумар б), Г. И. Попова ${ }^{\text {() }}$, Я. С. Высоцкая ${ }^{\text {2) }}$ \\ а, в, г) Уральский федеральный университет им. первого Президента России Б. Н. Ельцина, \\ Екатеринбург, Российская Федерация \\ 6) Технологический университет Нетаджи Субхаса, Нью-Дели, Индия \\ a) https://orcid.org/0000-0002-2063-4970, e-mail:n.l.antonova@urfu.ru \\ 6) https://orcid.org/0000-0002-8053-9158 \\ в) https://orcid.org/0000-0002-6597-8670 \\ r) https://orcid.org/0000-0002-1081-7693
}

\title{
Влияние краткосрочных образовательных программ региональных вузов на социально-экономическое развитие региона
}

В последнее время университеты все чаще рассматриваются в качестве драйверов регионального экономического развития. В данном исследовании проанализирована краткосрочная академическая мобильность студентов как фактор интернационализации высшего образования. Количество иностранных студентов (International Student Ratio) - это значимый показатель в глобальных рейтингах университетов. поэтому вузы, стремящзеся улучшить свои позиции на мировом образовательном рьнке, активно реализуют программы привлечения иностранных студентов. Краткосрочные образовательные программы академической мобильности характеризуются большой гибкостью, что позволяет удовлетворить широкий спектр потребностей и интересов потенциальных студентов. $B$ июле 2019 г. авторами проведен опрос среди индийских студентов ( $n=65)$, участвующих в программах краткосрочной международной академической мобильности в Уральском федеральном университете (Екатеринбург, Россия). Основная иель эмпирического исследования - изучение роли краткосрочных образовательных программ, реализуемых региональным университетом, в социоэкономическом развитии региона, а также иенности краткосрочной академической мобильности индийских студентов в реализаиии жизненных стратегий. Выявлены проблемы, препятствующие эфбективной реализации краткосрочных образовательных программ в вузах. Результаты исследования показали, что реализачия международных образовательных программ ведет к прямым и косвенным экономическим преимуществам и выгодам (иностранные студенты выступают источником дохода и потенциальным актором международного сотрудничества региона). Материалы опроса индийских студентов свидетельствуют о том, что, во-первых, российское образование повышает статусные позиции иностранного студента, способствует успешному карьерному продвижению и становится «мягкой силой» в выстраивании дальнейших международных связей и отношений; во-вторых, знакомство с системой высиего образования формирует потребность продолжить обучение в магистратуре российского университета, укрепляя статус региона и стимулируя платежеспособный спрос на образовательные услуги.

Ключевые слова: интернационализация, университет, академическая мобильность, краткосрочные программы, индийские студенты

\section{Благодарность}

Исследование выполнено при финансовой поддержке гранта Российского научного фонда № 18-18-00236, выцанного Уральскому федеральному университету.

Для цитирования: Антонова Н. Л., Кумар Д. А., Попова Г. И., Высоцкая Я. С. Значение краткосрочных программ для регионального университета // Экономика региона. 2021. Т. 17, вып. 2. С. 460-472. https://doi.org/10.17059/ekon. reg.2021-2-8

\section{Introduction}

Internationalisation of higher education is a priority task for almost all modern higher education systems. According to researchers, the increasing popularity of cross-border education, growing mobility of students and university professors, development of global scientific cooperation and international partnership have become a response to globalisation processes [1-3].

Russian universities have intensified activities aimed at increasing their competitiveness in the global educational market by exporting educational services and asserting their positions in international rating systems. Academic mobility is increasingly becoming an indicator of university success and its resilience in the system of international relations.

In this context, regional universities located in non-capital cities face a serious challenge. On the one hand, such universities are focused on local labour markets, satisfying their needs in qualified personnel, solving issues of accelerated development and contributing to the implementation of technological innovations. As such, regional universities operate in close cooperation with regional businesses, industries, research centres and authorities. On the other hand, responding to the requirements of education internationalisation, regional universities are supposed to satisfy the needs of foreign students. From this per- 
spective, it becomes important for a regional university to go beyond its local territorial interests and take into account the needs of subjects from global markets. Therefore, when developing marketing strategies, modern regional universities need to transform their educational, research, innovative and administrative spheres such that the requirements of international university rankings could be met.

A popular internationalisation strategy pursued by many regional universities consists in the attraction of foreign students to both long-term and short-term educational courses, such as exchange or internship programmes. In this paper, we investigate short-term academic mobility as a mechanism for promoting the internationalisation of a regional university.

\section{Short-Term Academic Mobility of Students}

Universities in many countries include shortterm academic mobility programmes in their internationalisation policies. In accordance with the Bologna Declaration, two main forms of student mobility can be distinguished. The first is the socalled degree mobility, i.e. enrolling students for obtaining a degree abroad. The second is the socalled credit mobility, i.e. a limited period of training abroad for the purpose of obtaining credits in particular subject areas.

In the context of the growth of global educational markets and the increasing role of international education rankings, universities introduce new forms of student academic mobility. A popular approach is to offer short-term training programmes covering from 1-2 weeks to several months, e.g. summer or winter schools, internship programmes, study tours, etc. The advantages of such programmes consist in the absence of the need to follow strict governmental requirements of state educational standards and a certain level of flexibility, since organisers can respond promptly to the changing local contexts by offering products most demanded on the educational market.

The main goal of short-term academic programmes consists in acquainting students with the specifics of professional communication in international contexts [4] to gain the experience of interaction with representatives of different cultures [5]. E. Wood and H. St. Peters note that "study tours" are not holidays but rather educational trips that boost the development of cross-cultural competencies [6]. According to V. Cooper, students participating in academic mobility programmes and experiencing intercultural interactions become prepared to pro- fessional collaboration with representatives of other cultures and social systems [7]. In addition, short-term mobility allows educational migrants to compare training models and technologies in different systems. "Learning from contrast", as noted by U. Teichler, encourages the formation of critical thinking [8]. This experience is also valuable from the standpoint of reflecting on the student's own life trajectory, value system and behavioural style. Such people are more receptive and tolerant towards new ideas, innovative plans and projects [9]. Today, host universities treat academic mobility programmes as a context boosting the development of students' intercultural competences and cosmopolitical views, thereby offering additional employment advantages [10]. Experience of intercultural skills, formation of social capital and inclusion in the sociocultural environment of the host society - all these are important components of academic mobility programmes.

A possible vector of students' educational path is to enrol on a Master's or PhD programme abroad. According to the research by T.L. Lewis and R.A. Niesenbaum, more than half of the students having had the experience of short-term academic mobility opt for learning outside their home country in the future [11]. Admitting all the advantages of international academic experience, which can act as a driver of future collaborations between countries, modern governmental structures are increasingly aiming to create favourable conditions for boosting short-term educational mobility. Some countries offer more attractive employment options to such students [12] or use different models of financial and informational support [13].

A significant advantage of short-term academic mobility is the inclusion of students, who lack the opportunity (for certain reasons) to leave their country and/or their family for a long time, in global educational processes. For such people, short-term training abroad can be the only chance to obtain the experience of intercultural communication.

Selection of a host country or city for both short-term and long-term academic mobility programmes is a rather important question for educational migrants. Biao \& Shen [14] claim the existence of a reputational hierarchy, in which the United States (USA) nd the United Kingdom (UK) take the highest positions. This means that some countries and cities may possess more symbolic resources than individual universities [15]. At the same time, there are studies confirming the correlation between the university's ranking position 
(World-Class University) and students' choice of mobility programmes [16].

In general, the development of news forms of academic mobility indicates the growing complexity of institutional links across the global educational space, the establishment of new organisational structures aimed at attracting foreign students to implement their educational needs and interests.

\section{Academic Mobility as a Factor in the Socio- Economic Development of a Region}

All over the world, universities hold key positions as drivers of regional economic development $[17,18]$. According to A. Valero and J.V. Reenen, a $10 \%$ increase in the number of universities in a region is associated with about a $0.4 \%$ increase in the gross domestic product (GDP) per capita and other economic indicators. Research shows that even satellite university campuses contribute to the development of businesses and communities at the local level, making a corresponding contribution to the economic development of the region [19].

Foreign students as subjects of the higher education system take an active part in determining the status of a particular economic territory. Thus, an analysis conducted by Russian researchers [20] to determine the contribution of higher education to the social and economic development of Russian regions revealed that the demand for higher education in a certain region should be seen as an important indicator of its economic prosperity. This demand can be measured by either the number of students paying tuition fee from their own funds, or by the number of students, whose tuition fee is covered by enterprises or companies from targeted funds assigned for personnel training. In this case, education costs replenish the region's budget. Thus, during the 2018/2019 academic year, the USA hosted over one million students, and reported $\$ 44.04$ billion in education exports [21]. The national project "The development of the export potential of the Russian education system" claims that the income obtained from the export of Russian education is planned to grow by 5 times and reach 373 billion roubles by 2025 [22].

Moreover, according to some researchers, educational migrants may increase the amount of highly educated workforce in the host region. Thus, student migration from economically weaker countries to those economically stronger provides the labour market with highly qualified specialists, thus benefitting the overall economic situation in the host region $[23,24]$.
Direct and indirect economic advantages and benefits associated with international educational programmes have stimulated the interest of both national governments and individual universities (regional included) in increasing the share of educational migrants in the overall number of students. Economically advanced countries are more attractive in terms of academic mobility, and governmental (federal, regional) bodies see foreign students as human resources that contribute significantly to economic development and international competitiveness [25]. Hence, factors affecting the choice of the country, including the convenience of transportation, visa support, tuition fee, possibility of future employment, should be adjusted to take into account educational migrants' demands. This requires the development of strategies for improving the positions of regional universities in the global education market.

In our opinion, there is one more important aspect. In the long run, foreign students should be seen as an important resource for Russian regions. Having returned to their home country and having started a career there, yesterday's Russian students could affect the social and economic development in the region, where they once studied. This happens indirectly (through social contacts), provided that the experience was positive [26, 27]. In practice this influence could be realised, for example, through unconscious recruiting of potential students to that regional university or maintaining mutually beneficial collaboration with particular regional enterprises or organisations.

Ongoing global changes promote international competition between universities, including in the sphere of attracting foreign students. Such students act not only as a source of economic income, but also as a prospective actor of economic collaborations in the future. Therefore, by participating in academic mobility programmes, foreign students contribute to the economic regional growth (tuition fee and other expenses not connected directly to education) in the long run. Even short-term educational programmes have positive economic effects for the host region by stimulating interest of foreign citizens in the territory.

\section{Higher Education in India: Students as a Subject of Academic Mobility}

The higher education system in India was brought by the British Colonialists with the primary objective to spread European science and literature and develop a loyal English-speaking workforce to administer its colony. The students admitted to these institutes came mainly from India's upper classes. The first institutions of 
higher learning were set up in 1857: these were the University of Calcutta, the University of Madras and the University of Bombay [28].

After independence in 1947, there has been a rapid growth of educational institutions in India. Established as a decentralised country with federal system of government, with 28 states and 9 union territories, education is the shared responsibility of the Union and the State. The educational system is administered at the state level by the department of education of individual states, while the federal government (through the Ministry of Human Resources Development (MHRD)) sets overall policy objectives and guidelines at the national level. Higher educational institutions may be broadly classified as Central universities, State universities, Private universities, Deemed-to-beuniversities and Institutes of National Importance.

In the last few decades, the higher education system has grown phenomenally. It is the largest in terms of the number of institutions and second largest in terms of student enrolment. The number of private institutions have grown much larger as compared to the government supported institutes [29]. According to MHRD report, $77.8 \%$ of the colleges in India are privately owned. Many of these private unaided colleges have lower admission requirements in terms of academic grades, as compared to public colleges, as they focus is on increasing the student enrolment. However, they are found to charge much higher admission fees by Indian standards.

The government funded institutions or public institutions are regulated (but often underfunded) and very bureaucratic in their procedures. The majority of these follow an affiliating university model, with a university or a government authority as their supervisory authority [30]. They often lack the capacity to effectively monitor their affiliated colleges. According to a report, more than $70 \%$ of the students study at local and regional universities which are poorly funded with poor infrastructure, except the "Institutes of Eminence". These are highly selective institutions that receive special funding support from central government. Admission to these institutions is based on qualifying competitive entrance examinations held at the state and national level. The demand for admission to these institutions far exceeds the available seats. As a result, this situation has led to an increase in private coaching institutes, which prepare aspiring candidates for the competitive entrance examinations.

Though, in principle, admission to these educational institutions is open to all eligible students, irrespective of their caste, creed, religion or lan- guage background, disparities are observed in the gross enrolment ratio among different sections of the society. The caste-based and hereditary social stratification in India has led to structural and systemic exclusion and deprivation of large sections of people belonging to lower castes in India [31]. Acknowledging their economic, social, political and educational deprivations, the Constitution of India has made several provisions to protect and promote their well-being. One of them is the reservation of seats for the marginalised segments of these sections, subsidised fees and scholarship schemes in higher education. As a result of these proactive policies of the government, inequities in educational attainments across social groups have begun to narrow down according to some reports. Despite these efforts, their gross enrolment ratio (GER) continues to be low for various socio-economic reasons [32].

Several studies and industry reports have raised concerns about the quality of teaching and learning in higher educational institutions. This excludes some central universities and those recognised as institutes of eminence by the government. In the other universities, it has been observed that a large number of engineering graduates are not employable in the industry, because of poor quality education, lack of competencies, a widening gap between the college curricula and market demands [33, 34].

Over the last few decades, there has been a significant growth in the momentum of Indian students going for studying in foreign universities. First, many factors have played an important role in this trend. Institutions which are reputed for providing quality education, such as the Indian Institutes of Technology (IITS), Indian Institutes of Management (IIMs) and some premier medical schools, and subsequently high salary employment prospects, are far fewer than their demand in this hugely populated country. This has resulted into fierce competition for admissions, in spite of strong academic grades $[35,36]$.

Second, Indian education system has focused on clear demarcated disciplines such as science and engineering, law and medicine (however, many new reforms, such as CBCS or Choice based credit system, have been recently implemented to promote flexibility in the choice of disciplines in bachelor and post-graduate programmes). Students interested in new career paths and global careers are seeking admissions in foreign universities.

Third, young people as well as their parents have wider exposure to the new educational and career prospects and opportunities available in 


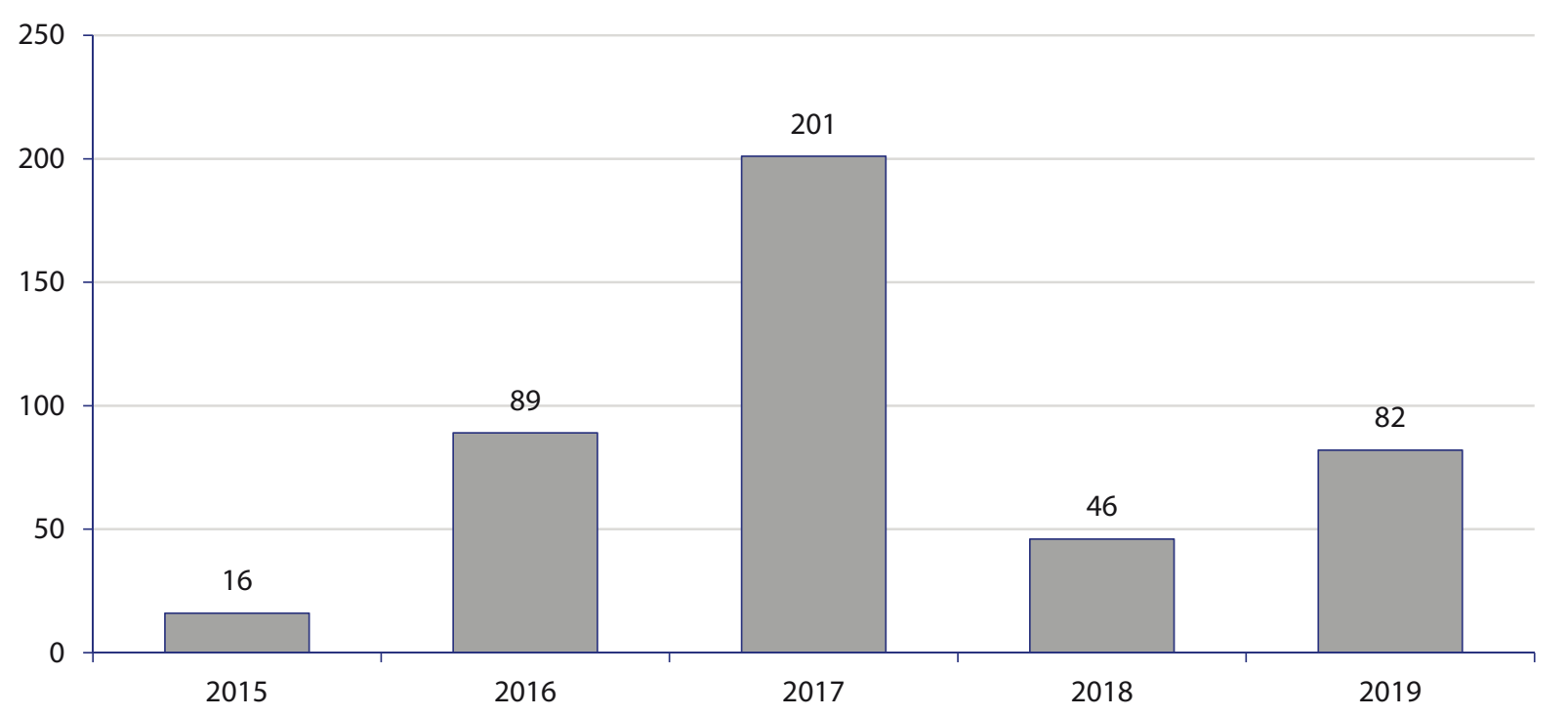

Fig. 1. The dynamics of Indian students participating in Russian short-term academic mobility programmes

western countries. More elite and rich people, many of whom are highly status conscious, are sending their children for higher education abroad for better educational experience and quality of life. According to the Reserve Bank of India (RBI), there is a significant increase in Indian students going abroad to pursue higher education. In fact, spending on tuition and hostel fees by Indians studying overseas has gone up by $44 \%$ from $\$$ 1.9 billion in $2013-14$ to $\$ 2.8$ billion in $2017-$ 18. According to the Ministry of External Affairs, Indian students are studying in more than 90 countries of the world. However, the USA, Canada and Australia are the most favoured destinations for Indian students for pursuing higher studies as their immigration policies allow students to seek employment after completing the courses [37].

Russia has been a destination for obtaining higher education for Indian students since 1950s. Universities of these two countries have many partnership agreements and have promoted joint programmes. The number of students from India in Russia is demonstrating a stable growing trend [38]. According to reports, one of the reasons for these growing trends is that Russian universities offer higher education at affordable prices compared with European and American universities. Fewer qualifying exams for admissions have been found to be an important consideration for seeking admission to the Russian universities [39].

\section{Study Design}

Since 2014, the Ural Federal University has been implementing "the Summer University” project in the framework of international short-term academic mobility, the goal of which is to attract foreign students and strengthen the universi- ty's position in the global educational space. In total, about 1,000 foreign students attended the Summer University programmes. The dynamics of Indian students participating in this project is presented in Figure 1.

Construction and mechanical engineering are the most attractive subjects for Indian students. Undoubtedly, the high interest in STEM disciplines is associated with the growing demand in India for specialists in engineering areas. On the other hand, the Russian engineering school enjoys excellent reputation all over the world.

Our research was conducted in July 2019. During this period, short-term educational programs were implemented at the Ural Federal University in the following areas: designing of metal and reinforced concrete structures, $R \& D$ in mechanical and electrical engineering. The programmes were attended by Indian students from such universities as the Vishvanikitan University, A.P. Shah Institute of Technology, Bharath University, BVM Engineering College.

In order to elucidate the prospects of shortterm academic mobility, the following research tasks were formulated:

- to characterise the underlying motivation for participation in a chosen programme;

- to determine the awareness of the content of the chosen educational programme and reveal expectations of Indian students;

- to identify difficulties encountered by Indian students during their training in Russia;

- to determine the role of short-term academic mobility in the future life plans of Indian students.

65 respondents were interviewed. The survey was conducted after classes, in the students' 
free time. The average duration of completing the questionnaire was 15 minutes. The gender structure of the respondent sample was 12 female and 53 male students. At the time of the survey, all the students were enrolled in a Bachelor's programme at their home universities; among them were 1 first-year student, 7 second-year students, 32 third-year students, 25 fourth-year students. The age distribution of the respondents was as follows: 14 respondents were younger than 20 years old; 41 respondents were $20-21$ years old; 10 respondents were $22-23$ years old.

We developed a questionnaire consisting of 16 questions: 5 closed questions, 3 open questions and 8 half-closed questions. Open questions were intended to give the students an opportunity to express their own opinion about their motivation for selecting Russia as an educational destination, as well as to assess the role of short-term academic mobility in the implementation of their future life plans.

It should be noted that, while developing the research methodology, we considered that almost all foreign students studying at Russian universities experience difficulties with the Russian language [40]. Therefore, the questionnaire was translated into English, which made it possible to lower the language barrier during the survey and to obtain sufficiently reliable and valid information.

The obtained data were processed using the Vortex sociological and marketing information analysis programme (version 10). The limitation of our study consists in a rather small respondent sample. Therefore, the obtained results should not be treated as representative. Rather, the obtained data aim to indicate general trends in the implementation of short-term international educational programmes of a large regional university.

\section{Results and Discussion}

According to our results, the leading motivation for Indian students to participate in shortterm training programmes is their personal interest. Every third respondent noted that they were well informed about the curricula of study and the organisation of training at the Ural Federal University. The choice of a programme was determined by the students' requirements in terms of obtaining new or developing existing competences in the field of research and development (R\&D) and implementation of innovative technologies in high-tech industries. In this regard, the Ural Federal University is seen as an attractive platform even for short-term training of foreign students: here, programmes are implemented on the basis of traditional educational forms and project activities with the involvement of large Ural industrial enterprises companies, including the Universitetsky Technopark, Chelyabinsk Pipe Rolling Plant, SVEL Company Group, etc.

Interest in Russia as a whole $(57.8 \%)$ and in the city of Ekaterinburg (20.3\%) in particular takes a special position in the motivational structure of Indian students. While taking the decision to study in Russia, students spent time getting acquainted with Russian history (34.4\%), culture and art (28.1\%), as well as conducting an analysis of the current political situation (29.7\%). It is important to note that the awareness of the socio-cultural context of the host country contributes to the successful adaptation of educational migrants to the foreign language, value system, social norms, traditions and customs. Every fourth respondent expressed their interest in studying (before coming to Russia) the standards of everyday practices of the Russian population, as well as the rules of conduct in various formal and informal situations. As our study showed, this knowledge was a significant factor in the overall satisfaction with staying in Russia. 16.9 \% of Indian respondents noted that the lack of knowledge concerning accepted norms of behaviour in stores, cafes and other public places was a major obstacle to a comfortable living in Russia.

When describing their impressions of the city of Ekaterinburg, Indian students indicated its regional nature and provinciality. At the same time, it is a large industrial centre, where the necessary conditions are created for the realisation of the needs and interests of various social groups, including students. The expectations of the majority of respondents (93.9\%) from studying at the university and staying in the city of Ekaterinburg corresponded to the real situation.

What difficulties did Indian students face while studying at a regional university? Our research materials show that the language barrier was one of the most serious problems for foreign students (73.8 \%). Language is the basic mechanism of human communication [40]. It should be mentioned that language barrier is a major problem in attracting foreign students to study in Russian regional universities [41-43]. The respondents indicated difficulties in both understanding university professors and interacting with the representatives of the host community on a daily basis (sellers, busmen, etc.). The lack of linguistic competence results in such psychological problems as increased uncertainty, fear of making a mistake, etc.

Almost every second respondent (42.1\%) mentioned the lack of habitual food, which was par- 
ticularly relevant for vegetarians. Gastronomic requests of Indian students are certainly a challenge for a regional university. Therefore, development of educational ties between Russia and India requires not only high-quality educational programmes, but also adaptation of the infrastructure of regional universities to the vital needs of foreign students.

Modernisation of the university environment in order to meet the requests of foreign students implies improving living conditions. $7.7 \%$ of the respondents noted the lack of domestic comfort. About the same number of students mentioned rather complicated bureaucratic procedures related to, e.g., obtaining a place in a university dormitory. Interestingly, foreign students in other Russian regional universities also indicate insufficiently comfortable living conditions and intricate bureaucracy as key disadvantages of studying in Russia. Thus, foreign students taking a course at the Penza State University noted poor conditions at dormitories, such as the absence of separate shower and kitchen, insufficient cleanliness and uncomfortable room temperature [44]. Among the reasons for foreign students' dissatisfaction with the living conditions in dormitories, respondents at the Yaroslavl State Technical University listed poor sanitary-hygienic conditions, low room temperature and insecurity [45]. D.S. Drozhzhina proposed an interesting interpretation: based on her research, the living conditions are perceived by students as "an inalienable part of everyday life" [46, p. 42].

Another problem pointed by Indian students was the climatic conditions. According to Ya.G. Semenova, the loss of interest in studies and increasing psychological discomfort are frequently connected to the difficulties of climate adaptation [47]. In a study by D.D. Gurko et al., $53.2 \%$ of foreign students from far-abroad countries mentioned the harsh climate as the main problem experienced during their arrival in Russia [48, p. 111]. In our study, $27.7 \%$ of the students complained of cold weather, although our survey was conducted in July - the hottest month in the Urals.

The interaction with educators was another area of dissatisfaction for $7.7 \%$ of the respondents. S.A. Pimonova and E.M. Fomina found that, although the language barrier itself was not seen as a serious problem, international students do not recommend education in Russia to their friends if they had a negative experience of communication with professors and tutors [49]. It is important to note that, in the context of the internationalisation of regional universities, educators are sup-
Table 1 Motives for choosing a Russian university for further studies (\% of respondents)

\begin{tabular}{|l|c|}
\hline \multicolumn{1}{|c|}{ Motivation } & \% of respondents \\
\hline $\begin{array}{l}\text { Prestige of having a foreign } \\
\text { university diploma }\end{array}$ & 56.6 \\
\hline Deepen and expand your education & 56.6 \\
\hline $\begin{array}{l}\text { Learn the culture and traditions of } \\
\text { another country }\end{array}$ & 54.7 \\
\hline $\begin{array}{l}\text { Plans to continue living and working } \\
\text { in Russia }\end{array}$ & 34.0 \\
\hline $\begin{array}{l}\text { Have more job opportunities after } \\
\text { returning home }\end{array}$ & 34.0 \\
\hline $\begin{array}{l}\text { Have the opportunity to } \\
\text { communicate with foreign students }\end{array}$ & 34.0 \\
\hline $\begin{array}{l}\text { Improve knowledge of the Russian } \\
\text { language }\end{array}$ & 22.6 \\
\hline Hard to answer & 3.8 \\
\hline Total: & 296.2 \\
\hline
\end{tabular}

* The sum of the responses exceeds $100 \%$, because respondents were given the opportunity to choose several answers.

posed to expand their competences to develop those necessary for teaching students from other countries. The professional functions and social role of professors should imply their awareness of the specific features of intercultural communications: a modern university professor should possess fundamental knowledge of the culture of their students.

$64 \%$ of our Indian respondents expressed their willingness to continue education in Russia, which indicates a high level of satisfaction with learning at a Russian university. The respondents identified the following motives for choosing Master's and PhD programmes in Russia (Table 1).

The results of the conducted survey show that, along with the prestige of obtaining Russian higher education, Indian students aspire to develop intercultural competencies: “... your country, your culture, your people are really beautiful” (male), "next time I would like to write: my country, my culture ..." (male), "I like Russian culture and customs" (female), "Russians love Indians ..." (male). The high quality of Russian education was also mentioned by foreign students learning at other Russian regional universities [50, 51]. Researchers investigating the potential of academic mobility in Kazakhstan discovered interest in terms of the possibility of intercultural communication and inclusion in everyday Russian practices: "it would be interesting to live there because of interesting places and entertainments" [52]. Among attractive aspects of Russian higher education, Indian students also mentioned its applied character: project training provides ample opportunities for im- 
plementing the gained competences in future professional life.

The results of our study show that Russian university education is a status characteristic for Indian students, which provides the opportunity to develop socio-cultural and communicative competences and to build life trajectories in a foreign country.

Naturally, not all Indian students expressed their desire to continue education in Russia after completing short-term academic mobility programmes. Among the main factors against such a decision were to following: a half of the respondents mentioned the insufficient knowledge of the Russian language; one in four noted the reluctance to live away from their home country; the same proportion of respondents did not plan further education at all. The financial question also mattered: although, the quarter of the respondents had the necessary financial reserves to pay the tuition fee, every second student claimed that the lack of financial support could become the main difficulty in entering a Russian university.

Russian researchers investigated various aspects of providing support to participants of international educational projects. Thus, when considering the mechanisms of academic mobility in Germany, A.A. Shakirova found that the German experience could be applied in Russia. Among such measures are the formation of a regulatory framework and special funds supporting student mobility [53]. Some Russian universities develop student scholarship competitions. A good case in point is the projects realised at the People's Friendship University of Russia (RUDN) for both boosting incoming academic mobility (Top Student Mobility) and outcoming academic mobility (RUDN International Scholarship) [54]. Unfortunately, Russian regional universities are currently implementing few scholarship programmes for foreign students.

Alongside Russia, Germany and the USA were mentioned as the most attractive short-time educational destination: every third respondent designated universities in these countries as desirable for study. The motivation for choosing universities in Germany and the USA is associated not only with the high reputation of educational programmes there, but also with the high level and quality of life. According to Indian students, Germany and US "have the best universities with a friendly staff and high quality education" (male), "you can get good competences in my area of interest for research and further professional development (male), "good programmes in my field of interests" (male), "the lack of the language barrier" (female).

We requested our respondents to describe how the experience of short-term academic mobility would influence the implementation of their future life plans. Almost all respondents noted the uniqueness of the gained experience. Moreover, Indian students associated the period of education with gaining educational, cultural and communicative experience. This experience, according to one of the respondents, "... gives me the opportunity to understand my level of knowledge and gives me confidence" (male). Self-confidence, expansion and deepening of knowledge, intercultural communication allow us to take a fresh look at ourselves and our place in the world: "... I came across a different spectrum of possibilities ..." (male). The respondents claimed that short-term educational programmes contribute to determining further professional intentions: "This programme will play an important role in my career" (male), “... will give a good impetus to my professional development” (male), “... will increase my competitiveness" (female).

Russian participants in international educational programmes (particularly in the field of linguistics) also noted the positive effect of shortterm courses on the development of cross-cultural competences, encouraging the process of learning about the culture of host countries [55].

Along with obtaining prestigious education that will improve the respondents' future career prospects, Indian students received valuable information about Russia, a large regional Russian university and the daily life in a big industrial city. The combination of this knowledge, as well as the positive impressions from staying in Ekaterinburg, can be seen as factors in the implementation of soft power mechanisms through education. Having mastered social norms and values of a host community, foreign students are certain to rely on them in their future professional activities and social life [56].

According to A.L. Arefiev and N.M. Dmitriev, the potential of Russian-Indian cooperation is yet to be fully realised [57]. The estimates by E.F. Galyamova and G.O. Kudiman show that, although the largest share of all educational migrants to Russia are from former USSR countries, the number of Indian students seeking education in Russia will be steadily increasing [58]. It seems particularly important to further expand and deepen the interaction in the field of engineering education in accordance with the demands of labour markets in order to meet the needs of potential students. 


\section{Conclusions}

Our research has allowed us to draw a number of conclusions. In the context of the internationalisation of education, universities seek to attract foreign students by developing and offering academic mobility programmes, including short-term ones, which have several advantages: the lack of strict governmental regulations and the possibility of flexible management following changing market requests. The conducted survey among Indian students showed that interna- tional short-term academic mobility contributes to developing intercultural competences and building an adequate and efficient educational trajectory. The motivation of Indian students to study in Russian universities becomes an impetus for the development of the university infrastructure in terms of creating comfortable living conditions for foreign students. In the long run, this becomes a factor in strengthening the position of regional universities both on the national scale and globally.

\section{References} 244.

1. Knight, J. (2008). Higher education in turmoil: The changing world of internationalization. Rotterdam: Sense Publishers,

2. Hanley, L. (2005). Academic capitalism in the new university. Radical Teacher, 73, 3-7.

3. Slaughter, S. \& Rhoades, G. (2004). Academic Capitalism and the New Economy: Markets, State and Higher Education. Baltimore: Johns Hopkins University Press, 384.

4. Slotkin, M. H., Durie, C. J. \& Eisenberg, J. R. (2012). The benefits of short-term study abroad as blended learning experience. Journal of International Education in Business, 4(2), 163-173. DOI: 10.1108/18363261211281762.

5. Miao, S. Y. \& R. Harris. (2012). Learning and personality on study tours abroad. Research in Post-Compulsory Education, 17(4), 435-452. DOI: 10.1080/13596748.2012.738981.

6. Wood, E. \&St. Peters, Y. H.Z. (2013). Short-term cross-cultural study tours: impact on cultural Intelligence. International Journal of Human Resource Management, 25(4), 558-570.

7. Cooper, V. (2009). Intercultural student interaction in post-graduate business and information technology programs: the potentialities of global study tours. Higher Education Research \& Development, 28(6), 557-570.

8. Teichler, U. (2017). Internationalisation Trends in Higher Education and the Changing Role of International Student Mobility. Journal of international Mobility, 5(1), 177-216.

9. Williams, K. \& Best, G. (2014). Short Study Tours Abroad: Internationalizing Business Curricula. Journal of Teaching in Travel and Tourism, 4(3), 240-259.

10. Dall'Alba, G. \& Sidhu, R. (2013). Australian undergraduate students on the move: experiencing outbound mobility. Studies in Higher Education, 40(4), 721-744.

11. Lewis, T. L. \& Niesenbaum, R. A. (2005). Extending the stay: Using community-based research and service learning to enhance short-term study abroad. Journal of Studies in International Education, 9, 251-264. DOI: 10.1177/1028315305277682.

12. Jowi, J. O. (2009). Internationalization of higher education in Africa: Developments, emerging trends, issues and policy implications. Higher Education Policy, 22(3), 263-281.

13. Malveaux, G. F. \& Raby, R. L. (2019). Study abroad opportunities for community college students and strategies for global learning. IGI Global, 324.

14. Xiang, B. \& Shen, W. (2009). International student migration and social stratification in China. International Journal of Educational Development, 29, 513-522.

15. Prazeres, L., Findlay, A., McCollum, D., Sander, N., Musil, E., Krisjane, Z. \& Apsite-Berina, E. (2017). Distinctive and comparative places: alternative narratives of distinction within international student mobility. Geoforum, 80, 114-122.

16. Souto-Otero, M. \& Enders, J. (2017). International students' and employers' use of rankings: a cross-national analysis. Studies in Higher Education, 42(4), 783-810.

17. Belenzon, S. \& Schankerman M. (2013). Spreading the word: Geography, policy and knowledge spillovers. Review of Economics and Statistics, 95(3), 884-903.

18. McGill Peterson, P. (2014). Diplomacy and education: A changing global landscape. International Higher Education, 75, 2-3. DOI: 10.6017/ihe.2014.75.5410.

19. Rossi, F. \& Goglio, V. (2020) Satellite university campuses and economic development in peripheral regions. Studies in Higher Education, 45(1), 34-54. DOI: 10.1080/03075079.2018.1506917.

20. Leshukov, O. V., Evseeva, D. G., Gromov, A. D. \& Platonova, D. P. (2017). Otsenka vklada regionalnykh sistem vysshego obrazovaniya $v$ sotsialno-ekonomicheskoe razvitie regionov Rossii [Assessment of the Contribution of Regional Higher Education Systems to the Socio-Economic Development of the Russian Regions]. Moscow: HSE, 30. (In Russ.)

21. Education service exports. Retrieved from: https://www.trade.gov/education-service-exports (Date of access: 20.08.2020).

22. Pasport prioritetnogo proekta "Razvitie eksportnogo potentsiala rossiyskoy sistemy obrazovaniya" [Passport of the priority project "Development of the export potential of the Russian education system"]. Retrieved from: http://government. ru/projects/selection/653/28013/ (Date of access: 20.08.2020). 
23. Mok, K. H. (2010). The global economic crisis and educational development: responses and coping strategies in Asia. Journal of Education Policy, 25(6), 777-784. DOI: 10.1080/02680939.2010.510641.

24. Docquier, F., Turati, R., Valette, J. \& Vasilakis, C. (2019). Birthplace diversity and economic growth: evidence from the US states in the Post-World War II period. Journal of Economic Geography, 20(2), 321-354. DOI: 10.1093/jeg/lbz016.

25. Levent, F. (2016). The economic impacts of international student mobility in the globalization process. Journal of Human Sciences, 13(3), 3853-3870. Retrieved from: https://www.j-humansciences.com/ojs/index.php/IJHS/article/ view/3877 (Date of access: 25.08.2020).

26. Soo, K. T. \& Elliott, C. (2010). Does price matter? Overseas students in UK higher education. Economics of Education Review, 29(4), 553-565. DOI: 10.1016/j.econedurev.2009.10.016.

27. Cloete, N. (2012). Higher Education and Economic Development in Africa: The Academic Core. In: M. Vukasović, P. Maassen, M. Nerland, B. Stensaker, R. Pinheiro, A. Vabø (Eds.), Effects of Higher Education Reforms: Change Dynamics (pp. 137-152). Rotterdam: Sense Publishers.

28. Trines, S. (2018). Education in India. World Education News + Reviews. Retrieved from: https://wenr.wes. org/2018/09/education-in-india (Date of access: 25.08.2020).

29. Angom, S. (2015). Private universities in India: Growth, status and concerns. NUEPA occasional papers 46 . New Delhi: National University of Educational Planning Administration, 66. Retrieved from: http://niepa.ac.in/download/ Publications/OP_46_-_Sangeeta_Angom.pdf (Date of access: 25.08.2020)

30. Krishnan, V. B. (2019). In charts: The state of higher education in India. The Hindu. Retrieved from: https://www. thehindu.com/news/national/in-charts-state-of-higher-education-in-india/article29566829.ece (Date of access: 25.08.2020)

31. Indian Higher Education - Quest for Excellence. (2013). New Delhi: University Grants Commission, 42. Retrieved from: https://ugc.ac.in/pdfnews/7580771_Flag-ship-Programmes-of-UGC.pdf (Date of access: 25.08.2020)

32. Basant, R. \& Sen, G. D. (2014). Access to Higher Education in India: An Exploration of Its Antecedents. Economic and political weekly, 49(51), 38-45.

33. Singh, A. \& Singh, A. (2014). Private Engineering Education in India: Past, Present and Future. International Journal of Management and Social Sciences Research (IJMSSR), 3(11), 39-46.

34. Gupta, V., Kelkar, M., Noone, D. \& Malik, N. (2019). Shaping the future: Delivering on the promise of Indian higher education. Deloitte insights. Retrieved from: https:/www2.deloitte.com/us/en/insights/focus/reimagining-higher-education/indian-higher-education-sector.html (Date of access: 25.08.2020)

35. Bose, S. (2019). Is Studying Abroad worth it? Arguments and Statistics. Stoodnt. Retrieved from: https://www. stoodnt.com/blog/studying-abroad-worth-it/ (Date of access: 25.08.2020).

36. Sethi, R. (2019). Trends for studying abroad in 2019: Top courses, top countries and more. India Today. Retrieved from: https://www.indiatoday.in/education-today/study-abroad/story/trends-overseas-education-industry-in-2019-d ivd-1431292-2019-01-15 (Date of access: 25.08.2020).

37. Russian University Application for Indian Nationals. (2018). Study in Russia. Retrieved from: https://studyinrussia. $\mathrm{ru} / \mathrm{en} /$ actual/articles/russian-university-application-for-indian-nationals/ (Date of access: 20.08.2020).

38. Kumari, J. (2019). Why Russia is a huge draw among foreign students. The Times of India. Retrieved from: http:// timesofindia.indiatimes.com/articleshow/72124909.cms?utm_source=contentofinterest\&utm_medium=text\&utm_campaign=cppst (Date of access: 25.08.2020).

39. Merenkov, A. V. \& Antonova, N. L. (2015). Problem of Social Adaptation of International Students in Russia. New Educational Review, 41(3), 122-132. DOI: 10.15804 / tner.2015.41.3.3.10.

40. Guzikova, M. O. (2019). Multilingualism in motion: evolution of the phenomenon. Vestnik Tomskogo gosudarstvennogo universiteta. Filosofiya. Sotsiologiya. Politologiya [Tomsk State University Journal of Philosophy, Sociology and Political Science], 49, 114-123. DOI: 10.17223 / 1998863X / 49/12 (In Russ.)

41. Gomilevskaya, G. A., Petrova, G. A. \& Kononov A. Yu. (2018). Chinese culture and its influence on entrepreneurship. Baltiyskiy gumanitarnyy zhurnal [Baltic humanitarian journal], 4(25), 227-230. Retrieved from: https://cyberleninka. $\mathrm{ru} /$ article/n/obrazovatelnyy-turizm-kak-mehanizm-mezhkulturnoy-adaptatsii-inostrannyh-abiturientov-vgues (Date of access: 25.08.2020). (In Russ.)

42. Beregovaya, O. A., Lopatina, S. S. \& Oturgasheva, N. V. (2019). Barriers of social and cultural adaptation of foreign students in Russian universities. Perspektivy nauki i obrazovaniya [Perspectives of Science and Education], 38(2), 108-118. Retrieved from: https://cyberleninka.ru/article/n/bariery-sotsiokulturnoy-adaptatsii-inostrannyh-studentov-v-rossiyskih-vuzah (Date of access: 25.08.2020). (In Russ.)

43. Mukha, V. N., Sergienko, N. L. \& Lysenko. A. I. (2019). Peculiarities of foreign students primary adaptation in Russian universities (on example of KubSTU). Istoricheskaya $i$ sotsialno-obrazovatelnaya mysl [Historical and Social-Educational Idea], 10(2-2), 120-126. Retrieved from: https://cyberleninka.ru/article/n/osobennosti-pervichnoy-adaptatsii-inostrannyh-studentov-v-rossiyskom-vuze-na-primere-kubgtu (Date of access: 25.08.2020). (In Russ.)

44. Bekker, I. L. \& Ivanchin, S. A. (2015). Problems of foreign students adaptation to the educational process at a Russian university (by the example of Penza State University). Izvestiya vysshikh uchebnykh zavedeniy. Povolzhskiy region. Gumanitarnye nauki [University proceedings. Volga region. Humanities], 4(36), 247-257. Retrieved from: https://cyberleninka.ru/article/n/problemy-adaptatsii-inostrannyh-studentov-k-obrazovatelnomu-protsessu-rossiyskogo-vuza-na-primere-penzenskogo-gosudarstvennogo (Date of access: 25.08.2020). (In Russ.) 
45. Modnov, S. I. \& Ukhova, L. V. (2013). Problems of Adaptation of Foreign Students Studying in the Technical University. Yaroslavskiy pedagogicheskiy vestnik [Yaroslavl pedagogical bulletin], 1(2), 111-115. Retrieved from: https:/cyberleninka.ru/article/n/problemy-adaptatsii-inostrannyh-studentov-obuchayuschihsya-v-tehnicheskom-universitete (Date of access: 25.08.2020). (In Russ.)

46. Drozhzhina, D. S. (2013). Studying the adaptation of foreign students: a discussion on methodology. Universitas, 1(3), 33-47. (In Russ.)

47. Semenova, Ya. G. (2018). Questions of adaptation of foreign students to the conditions of life and education in Russian universities. Vestnik nauki i obrazovaniya [Bulletin of Science and Education], 5(41), 62-66. Retrieved from: https:// cyberleninka.ru/article/n/voprosy-adaptatsii-inostrannyh-studentov-k-usloviyam-zhizni-i-obucheniya-v-rossiyskih-vuzah (Date of access: 25.08.2020). (In Russ.)

48. Gurko, D. D., Trostyanskaya, I. B., Sema, E. Y., Barsukov, A. A. \& Polikhina, N. A. (2019). Education of International Students in Russian Higher Education Institutions. M.: State autonomous Sociological research center, 308. (In Russ.)

49. Pimonova, S. A. \& Fomina, E. M. (2018). Growing attractiveness of Russian universities for international students. Universitetskoe upravlenie: praktika i analiz [University Management: Practice and Analysis], 22(4), 97-109. DOI: 10.15826/umpa.2018.04.043. (In Russ.)

50. Stepanova, B. B. (2014). Comparative analysis of the causes of foreign students' educational migration in Russian universities. Vestnik Buryatskogo universiteta. Filosofiya [The BSU bulletin. Series 5. Philosophy], 14(1), 67-71. (In Russ.)

51. Golubkina, T. M., Efimova, S. A., Kipriyanova, N. V., Petrosyan, D. I. \& Sokolova, M. V. (2018). Russian university through foreign students' eyes. Zapad - Vostok [West-East], 11, 223-239. DOI: 10.30914/2227-6874-2018-11-223-239. (In Russ.)

52. Rakisheva, B. I. \& Poletaev, D. V. (2011). Educational migration from Kazakhstan to Russia as one of the aspects of cooperation in the development of the customs union. Evraziyskaya ekonomicheskaya integratsiya [Journal of Eurasian Economic Integration], 3(12), 84-101. (In Russ.)

53. Shakirova, A. A. (2017). Students' academic mobility provision in Germany in the context of education internationalization. Obrazovanie i samorazvitie [Education and Self Development], 12(3), 62-73. DOI: 10.26907/esd12.3.06. (In Russ.)

54. Imankulova, N. B. \& Moshlyak, G. A. (2019). Students' International Academic Mobility in the Context of Internationalization of Higher Education (RUDN University Case). Vestnik Rossiyskogo universiteta druzhby narodov. Seriya: Mezhdunarodnye otnosheniya [Vestnik RUDN. International Relations], 19(3), 499-508. DOI: 10.22363/2313-06602019-19-3-499-508. (In Russ.)

55. Kostina, E. A. \& Khoroshilova, S. P. (2016). Impact of short-term academic mobility on professional training of a teacher. Sibirskiy pedagogicheskiy zhurnal [Siberian Pedagogical Journal], 1, 50-55. (In Russ.)

56. Stetar, J., Coppla, C., Guo, L., Nabiyeva, N. \& Ismailov, B. (2010). Soft power strategies: competition and cooperation in a globalized system of higher education. In: L. M. Portnoi, V. D. Rust, S. S. Bagley (Eds.), Higher Education, Policy and Global Competition Phenomenon (pp. 191-203). New York: Palgrave Macmillan. DOI: 10.1057 / $9780230106130 \_14$.

57. Arefiev, A. L. \& Dmitriev, N. M. (2016). Indian Students in Russia: Sociological and Statistical Profile. Indian Journal of Science and Technology, 9(44), 104703. DOI: 10.17485/ijst/2016/v9i44/104703.

58. Galiamova, E. F. \& Kudimana G. O. (2017). The attractiveness of Russian universities in the international market of educational services. Vestnik Udmurtskogo Universiteta. Seriya Ekonomika i pravo [Bulletin of Udmurt University. Series Economics and Law], 27(3), 21-26. (In Russ.)

\section{About the Authors}

Natalya L. Antonova - Dr. Sci. (Soc.), Professor of the Department of Applied Sociology, Ural Federal University; Scopus Author ID: 57038433100; Researcher ID: Q-1495-2015; https://orcid.org/0000-0002-2063-4970 (51, Lenina Ave., Ekaterinburg, 620014, Russian Federation; e-mail: n.l.antonova@urfu.ru).

Duru Arun Kumar - PhD in Sociology, Associate Professor, Department of Management Studies, Netaji Subhas University of Technology; https://orcid.org/0000-0002-8053-9158 (Sector 3, Dwarka, New Delhi, 110078, India; e-mail: darun@nsut.ac.in).

Galina I. Popova - Student, Institute of Natural Sciences and Mathematics, Ural Federal University; https://orcid. org/0000-0002-6597-8670 (48, Kuybysheva St., Ekaterinburg, 620026, Russian Federation; e-mail: galka3099@gmail.com).

Yana S. Vysotskaya - Director of the Department of International Educational Programs, Ural Federal University; https://orcid.org/0000-0002-1081-7693 (19, Mira St., Ekaterinburg, 620002, Russian Federation; e-mail: yana.aymasheva@ gmail.com).

\section{Информация об авторах}

Антонова Наталья Леонидовна - доктор социологических наук, профессор кафедры прикладной социологии, Уральский федеральный университет им. первого Президента России Б. Н. Ельцина; Scopus Author ID: 57038433100; Researcher ID: Q-1495-2015; https://orcid.org/0000-0002-2063-4970 (Российская Федерация, 620014, г. Екатеринбург, пр. Ленина, 51; e-mail: n.l.antonova@urfu.ru).

Кумар Дуру Арун - PhD в области социологии, доцент кафедры управленческих исследований, Технологический университет Нетаджи Субхаса; https://orcid.org/0000-0002-8053-9158 (Сектор 3, Дварка, Нью-Дели, 110078, Индия; e-mail: darun@nsut.ac.in). 
Попова Галина - студентка, Институт естественных наук и математики, Уральский федеральный университет им. первого Президента России Б. Н. Ельцина; https://orcid.org/0000-0002-6597-8670 (Российская Федерация, 620026, г. Екатеринбург, ул. Куйбышева, 48; e-mail: galka3099@gmail.com).

Высоцкая Яна Сергеевна - директор Департамента международных образовательных программ, Уральский федеральный университет им. первого Президента России Б. Н. Ельцина; https://orcid.org/0000-0002-1081-7693 (Российская Федерация, 620002, г. Екатеринбург, ул. Мира, 19; e-mail: yana.aymasheva@gmail.com).

Дата поступления рукописи: 03.09.2020.

Прошта реиензирование: 26.11.2020.

Принято решение о публикации: 23.03.2021.

Received: 03 Sep 2020

Reviewed: 26 Nov 2020

Accepted: 23 Mar 2021 